\title{
TOURISM SEASONALITY IN THE SPAS OF ROMANIA
}

\author{
Marius I. STUPARIU* \\ University of Oradea, Department of Geography, Tourism and Territorial Planning \\ 1 Universității St. 410087 Oradea, BH, Romania, e-mail: marius_stupariu@yahoo.co.uk

\section{Cezar MORAR} \\ University of Oradea, Department of Geography, Tourism and Territorial Planning \\ 1 Universității St. 410087 Oradea, BH, Romania, e-mail: cezarmorar@yahoo.com
}

\begin{abstract}
Citation: Stupariu, M. I., \& Morar, C. (2018). TOURISM SEASONALITY IN THE SPAS OF ROMANIA. GeoJournal of Tourism and Geosites, 22(2), 573-584. https://doi.org/10.30892/gtg.22225-312
\end{abstract}

\begin{abstract}
The paper aims at presenting the seasonality as one of the most important elements that influences significantly the tourist activities. The research methododology deals with the statistical analyze of the basic indicators that define the seasonal flows the arrivals of tourists, the overnight stays and the ratio between them and the average stay, having as main result the setting out of the tourist seasonality in the spa resorts in Romania. The interpretation of the results show that in these spa resorts the tourist season differs very little from the tourist season registered at the national level, the periods of the tourist season being approximately identical for of all three indicators. Further, the results show that in the case of tourists' arrivals, the seasonal tourism in Romania (May-September) is one month longer than the seasonal spa tourist season in Romania (June-September), in the case of tourists' overnight stays, the seasonal tourism in Romania (June-September) is identical with the seasonal tourism in the Romanian spa resorts (June-September), and in the case of the average tourists' stay, the seasonal tourism in Romania (June-November) is shorter by one month, compared to the seasonality of the spa resorts in Romania (May-November).
\end{abstract}

Key words: seasonality, tourist flows, arrivals, overnight stays, average stay, spa resorts, Romania

\section{INTRODUCTION}

Seasonality is a variation in tourism activity, caused by natural or socio-economic elements. It is usually associated with the annual seasons and, it has in most cases an identical repetitiveness. A specific feature in the traditional tourist services (Karadzhov, 2014), seasonality is a dominant but not well understood feature of tourism (Jang, 2004). It is the third largest industry in the world (Maghsoodi Tilaki et al., 2017), being crucial to the success of the tourism industry (Deery et al., 2009). When creating a product that is meant to be active for the whole year, for the tourist market, seasonality is one of the elements that,

\footnotetext{
* Corresponding author
} 
through specific policies, needs to be addressed. However, we should consider that some tourist products, for reasons related to seasonality, are only seasonally active (summer or winter). In fact, according to the Great Dictionary of Neologisms, seasonality is defined as "the appropriation of what is seasonal" (Marcu, 2000), and seasonally, according to the Explanatory Dictionary of the Romanian Language is defined as something "connected to a certain season, lasting for the season, referring to a season" (DEX, 2009).

As a factor affecting tourist activities, having to be overcome with relatively little research conducted (Butler, 1998), seasonality is responsible for the measures taken by tourism service providers to improve its direct and indirect effects, through specific methods, to accommodate the off-season tourism demand, like development of the cultural tourism products for example, as way to reduce seasonality (Borges, 2013). Seasonality is a great challenge for a large part of the tourism destinations (Connel et al., 2015), as these destinations have a "high" season when employment, tourists and the attached spending are at a peak, and a "low" season when employment, tourists and the attached spending are at the lowest (Ahas et al., 2007; Koc, Altinay, 2004; Morse \& Smith, 2015), this could represent a major constraint for the overall tourist growth (Rizal \& Asokan, 2014). Seasonality is also influenced by the natural and socio-economic elements. The natural elements refer to the climatic conditions and the succession of the seasons, and the socio-economic elements refer to the regime and structure of holidays, the vacations of the school year, the available leisure time, the personal habits, the frequency of the events (festivals, concerts, fairs etc) (Petrevska, 2013). From a different perspective, seasonality includes the supply side of the tourism system, like marketing, labor market, business finance, stakeholder management (Baum, 1999).

Academic environments in the literature have approached the issue from a variety of perspectives, and as such, seasonality is generally defined according to the context in which is studied, e.g. hospitality, tourism or leisure. Commons and Page (2001), for example, suggest that seasonality is indissolubly linked to tourism and that tourism flows are determined by both natural and transient natural factors (Commons \& Page, 2001). Manning and Powers $(1984,25)$ capture the essence of the problem in the following quote explaining the seasonality and negative effects: "The uneven distribution of the use of tourist facilities in time is one of the most widespread issues in tourism, causing inefficient use of resources, potential, the emergence of social problems and ecological support capacities, as well as administrative planning difficulties"(Manning, Powers, 1984, 25). Manning and Powers (1984) are concerned that in extra seasonal periods facilities and services may be underused. On the other hand, the implications of overloading facilities over seasonal periods may have negative effects on tourism. For example, seasonality may exert tremendous pressure on tourism businesses, which become vulnerable due to lack of coherence in tourism services. Consequently, any strategies that have been used to combat the negative effects of seasonality (as well as those used to increase its positive impact) can not be transferred across the industry. As a result of these general findings, a comprehensive review of the literature to identify the causes and effects of seasonality (with a particular focus on those businesses located in remote or isolated regions) is needed (Manning \& Powers, 1984). This paper analyzes the tourist seasonality, a vital component of tourism, in the spa resorts of national interest in Romania, where the tourist activity is dealing with the treatment based on the main natural factors (Ilieş et al., 2011).

\section{METHODOLOGY}

The analysis of the tourist seasonality lies at the basis of the concept of economic efficiency of the tourist facilities with accommodation functions. By analyzing the seasonality and its effects, it is attempted to maximize the profitability in tourism (Zaman \& 
Geamănu, 2006). From a larger perspective, the tourism seasonality can not be analyzed as in other economic activities, because, depending on the type of specific services, it is differentiated and distinct from them (Bârsan and Şuşu, 2013). The tourism activity shows a frequent unequal distribution of the demand for tourist services, equivalent to a pronounced concentration of arrivals of tourists in a certain or at certain times of the year, and the diminution or, in some cases, the cessation of arrivals of the tourists at other times of the year. These seasonal travel movements have organizational, economic and social effects and implications on agents who offers touristic services. In order to correctly assess the seasonal implications of tourism activities, a systematic approach to elements that have direct or indirect effects on seasonality (Bell et al., 2012) is needed:

- periodic modeling of time series, the introduction, application and comparison of different seasonal models;

- the estimation of the time series components and the broader implications this has for estimating the adjustment and the seasonal business cycle;

- quantification of seasonal errors, with error comparisons in seasonal modelbased adjustments;

- practical issues that occur in seasonal adjustment: Creating filters during the asymmetric trend cycle, dealing with both temporal and contemporary reference constraints, detecting day-to-day trading effects in monthly and quarterly time series, and use of diagnostics in conjunction with the seasonal adjustment model;

- detection and modeling of chronological series containing extreme values, development of new procedures and extension of previous works;

- alternative models and inferential procedures for analyzing seasonal economic time series;

- aspects of modeling, estimation, and prognosis for nonseasonal economic time series.

The present study was carried out taking into account two major elements: spa resorts of national interest (according to GD 852/2008), as well as the time series provided by the Romanian Institute of Statistics (www.insse.ro). Thus, for the spa resorts of national interest taken in this study, the following resorts or groups of resorts were chosen (Figure 1):

- Moneasa (Arad County)

- Slănic-Moldova (Bacău County)

- Băile Felix-1 Mai resorts (Bihor County)

- Sângeorz-Băi resort (Bistriţa-Năsăud County)

- Băile Herculane resort (Caraş-Severin County)

- Eforie Nord-Eforie Sud resorts (Constanta County)

- Mangalia-Olimp-Neptun resorts (Constanta County)

- Techirghiol resort (Constanta County)

- Covasna resort (Covasna County)

- Pucioasa resort (Dambovita County)

- Băile Tușnad resort (Harghita County)

- Geoagiu resort (Hunedoara County)

- Amara resort (Ialomita County)

- Sovata resort (Mureş County)

- Vatra Dornei resort (Suceava County)

- Buziaş resort (Timiş County)

- Băile Govora resort (Valcea County)

- Băile Olănești resort (Valcea County)

- Călimăneşti-Căciulata resorts (Vâlcea County)

- Voineasa resort (Valcea County) 


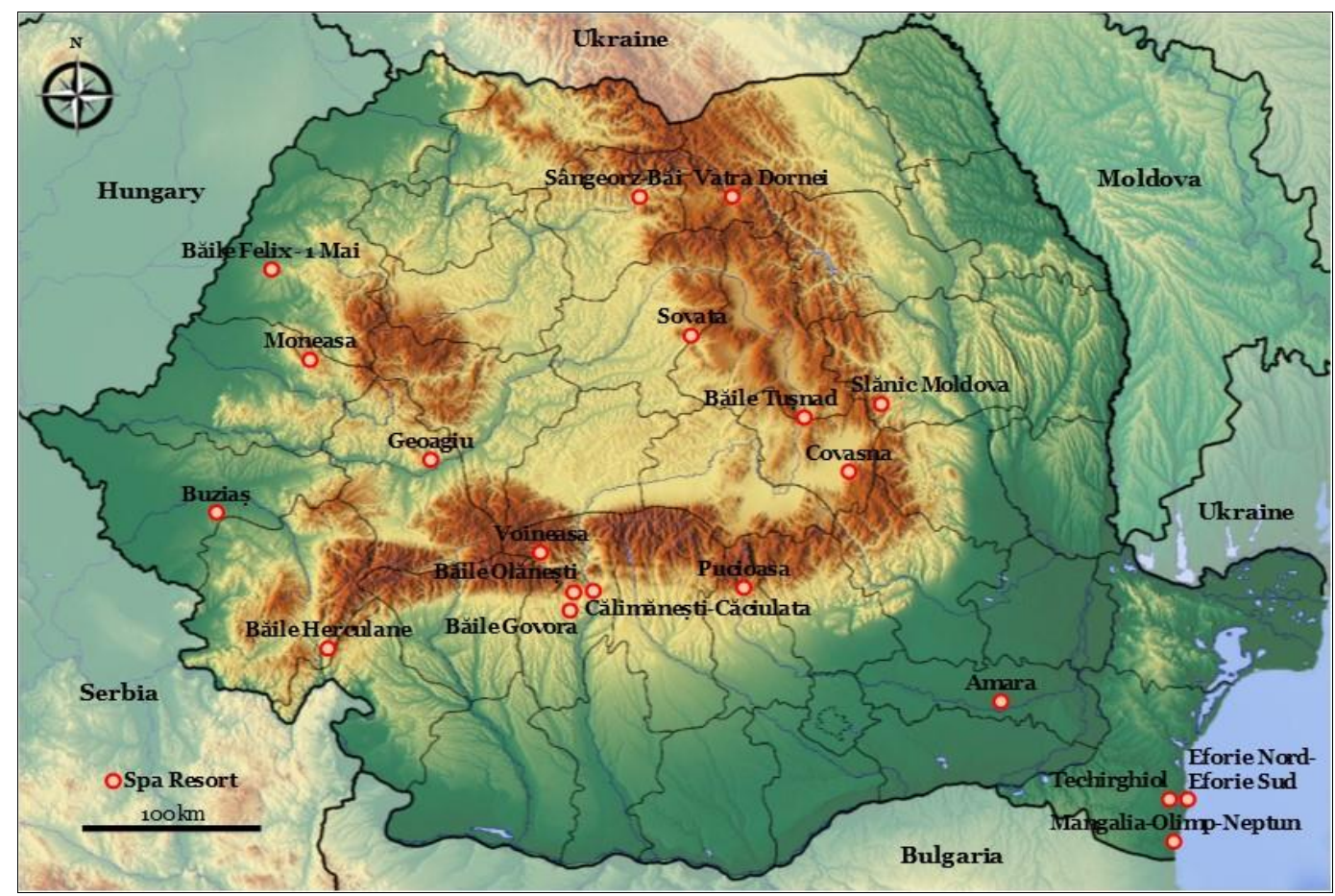

Figure 1. The spa resort of national interest of Romania (Source of map: GIS shape, with additions)

As for the time series, they have two variables: the actual period, which in the present study is monthly and has a temporal dispersion between January 2010 and December 2016 and the tourist flow, which in turn has for the analyzed part three subvariables: arrivals of tourists, overnight stays of tourists and respectively, the period of stay.

\section{ANNUAL TOURISM CIRCULATION}

\section{The Tourists Arrivals}

In the period 2010-2016, a total of almost 58 million tourists arrived in Romania. The average increase in tourists 'arrivals for the whole period was $80.6 \%$, and the annual average increase of tourists' arrivals was $10.5 \%$ (annual values ranged between $3.5 \%$ and $17.2 \%$ ). Thus, if in 2010 there were just over 6 million arrivals of tourists, in 2016 their number reached almost 11 million. At the same time, the average increase in the number of tourists' arrivals in the spa resorts in Romania for the whole period was $60.3 \%$, and the average annual increase in the number of arrivals of tourists was only 8.5\% (the annual values were between $-4.8 \%$ and $16.2 \%$ ). Thus, if in 2010 there were just over 850000 arrivals of tourists in spa resorts in Romania, in 2016 their number reached almost 1.4 million. On average, tourists arriving in spa resorts in Romania accounted for $12.9 \%$ of the total arrivals of tourists in Romania during 2010-2016 (average annual values ranging from $12.3 \%$ to 14.2\%) (Figure 2).

\section{The Tourist Overnight Stays}

The nearly 58 million tourists arriving in Romania between 2010-2016, generated nearly 150 million overnight stays. Similar to the number of tourists 'arrivals, tourists' overnight stays have increased year by year, throughout the studied period. Thus, the average number of tourists overnight stays increased by $58.3 \%$ and the average annual 
increase in tourists' overnight stays was 8.1\% (annual values ranging from $1.1 \%$ to $15.9 \%$ ). Thus, if in 2010 there were almost 16 million overnight stays of tourists, in 2016 the number reached over 25 million. Following the national trend, the average increase in the number of overnight stays in the spa resorts in Romania for the period 2010-2016 was 30.9\%.

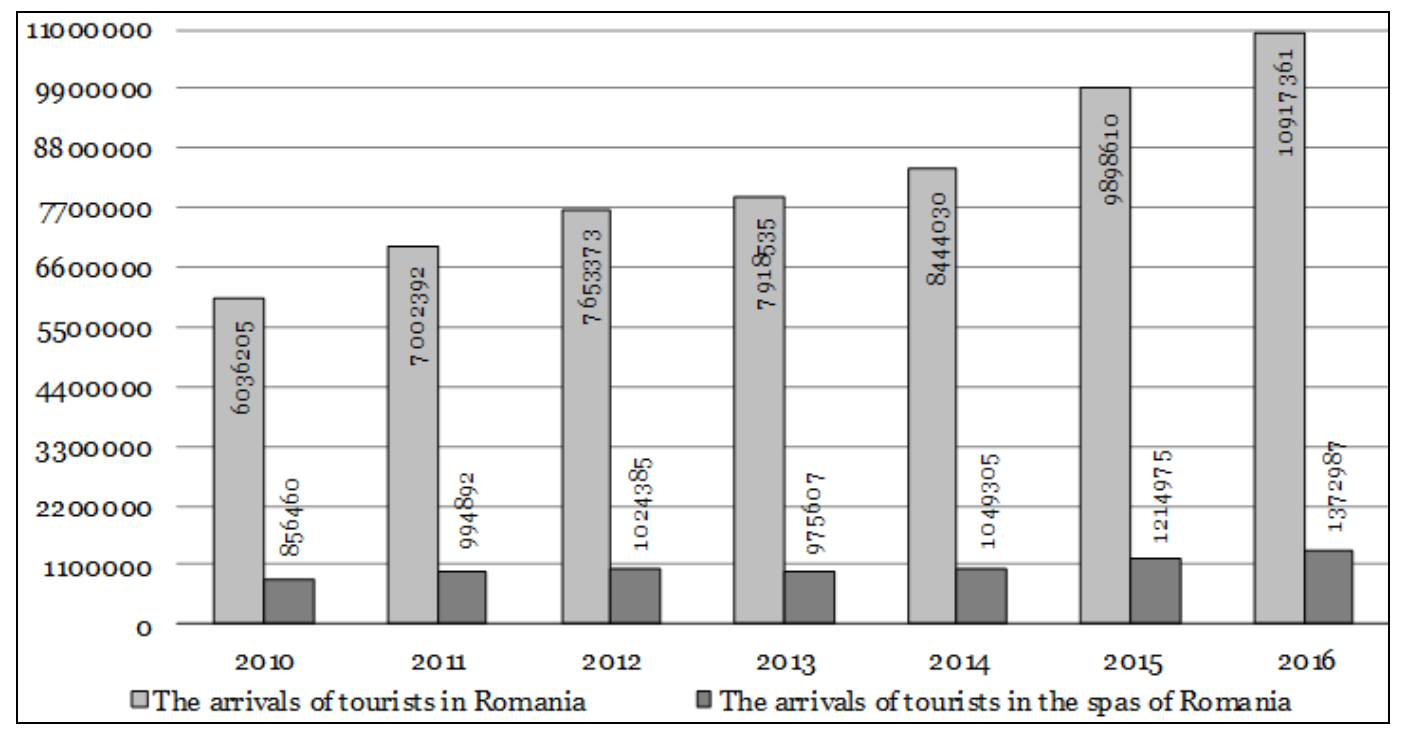

Figure 2. The arrivals of tourists in Romania and in the spas of Romania (Data source: http://statistici.insse.ro/shop/)

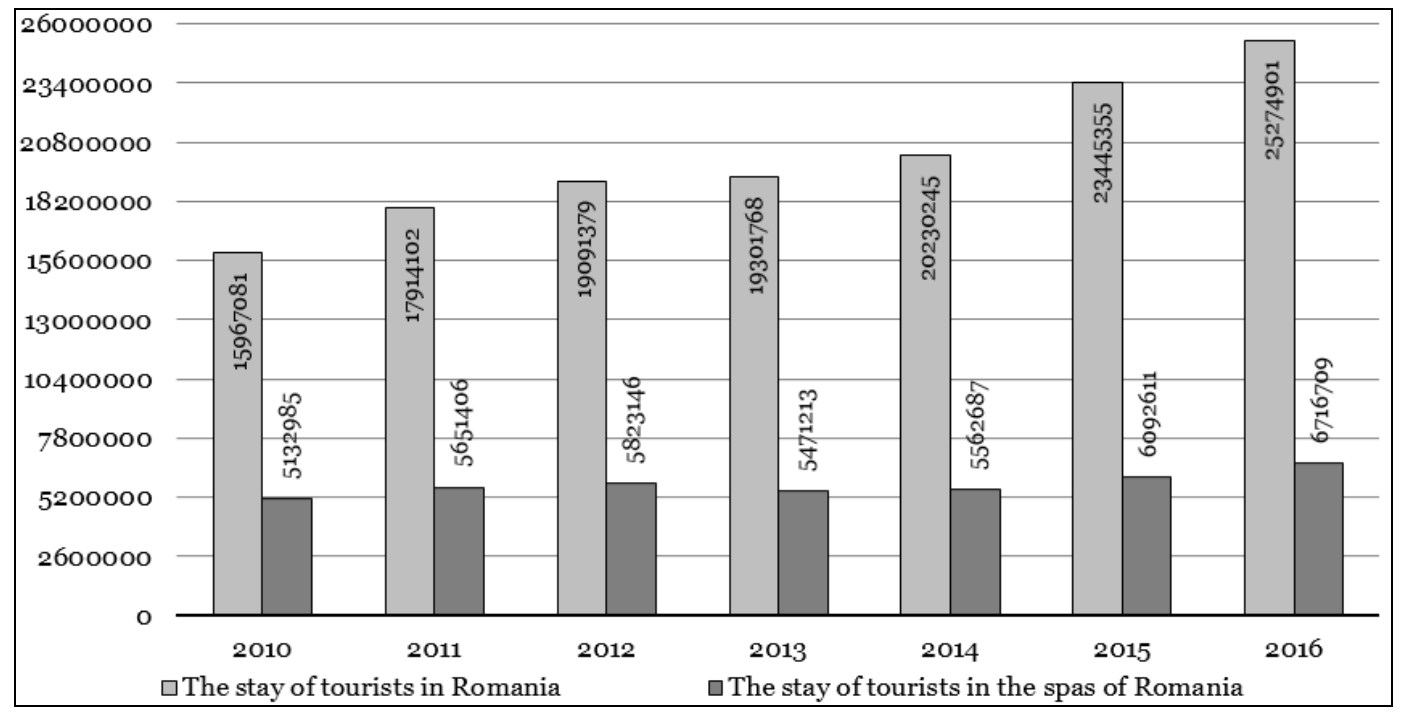

Figure 3. The stay of tourists in Romania and in the spas of Romania (Data source: http://statistici.insse.ro/shop/)

Under the same conditions, the average annual increase in the number of overnight stays of tourists was only $4.8 \%$ (annual values ranging from $-6.0 \%$ to $10.2 \%$ ). Thus, if in 2010 there were 5.1 million overnight stays in the spa resorts in Romania, in 2016 their number reached 6.7 million. Unlike tourists' arrivals in spa resorts in 
Romania, which accounted for an average of $1 / 7$ of the national flow, the number of overnight stays in the spa resorts in Romania represents almost 1/3, respectively $27.0 \%$ (the annual values ranged between 26.0\% and 32.1\% ) (Figure 3).

\section{The Average Tourist Stay}

From the ratio of the two above-mentioned indicators, the arrivals of the tourists and their overnight stays, we can determine the average stay. Thus, during the period 20102016, the 57870506 tourists arrived at national level generated 149856222 overnight stays, resulting in a national average stay of 2.36 days/stay. Throughout the study period (2010-2016), the annual average annual holidays decreased year-by-year, being recorded a decrease of $-12.7 \%$ and an annual average decrease of $-2.2 \%$ (the annual values were between $-3.9 \%$ and -1.0\%), from 2.55 days/stay in 2010 to 2.22 days/stay in 2016.

From the same ratio applied at the level of the arrivals and overnights indicators within the spa resorts in Romania, it results an average stay of 6.05 days/stay (from 7 488611 arrivals of the tourists in the spa resorts in Romania and 40450757 for the period 2010-2016) of overnight stays of tourists in spa resorts in Romania. Similar, at national level, in the spa resorts in Romania, the annual average stay has decreased year-by-year. The decrease for the whole studied period (2010-2016) was $-20.6 \%$ at an annual average rate of $-3.8 \%$ (annual values ranged between $-4.7 \%$ and $-1.8 \%$ ), from 6.83 days/stay in the year 2010 at 5.43 days/stay in 2016 .

The average stay recorded in the spas in Romania is significantly higher than the average stay in Romania, respectively 6.05 days/stay compared to 2.36 days/stay, resulting in a 2.6 times longer stay in favor of spa stays in Romania. Within each year the same situation is recorded, the differences being between 2.4 and 2.7 times higher in favor of spa stays in Romania (Figure 4).

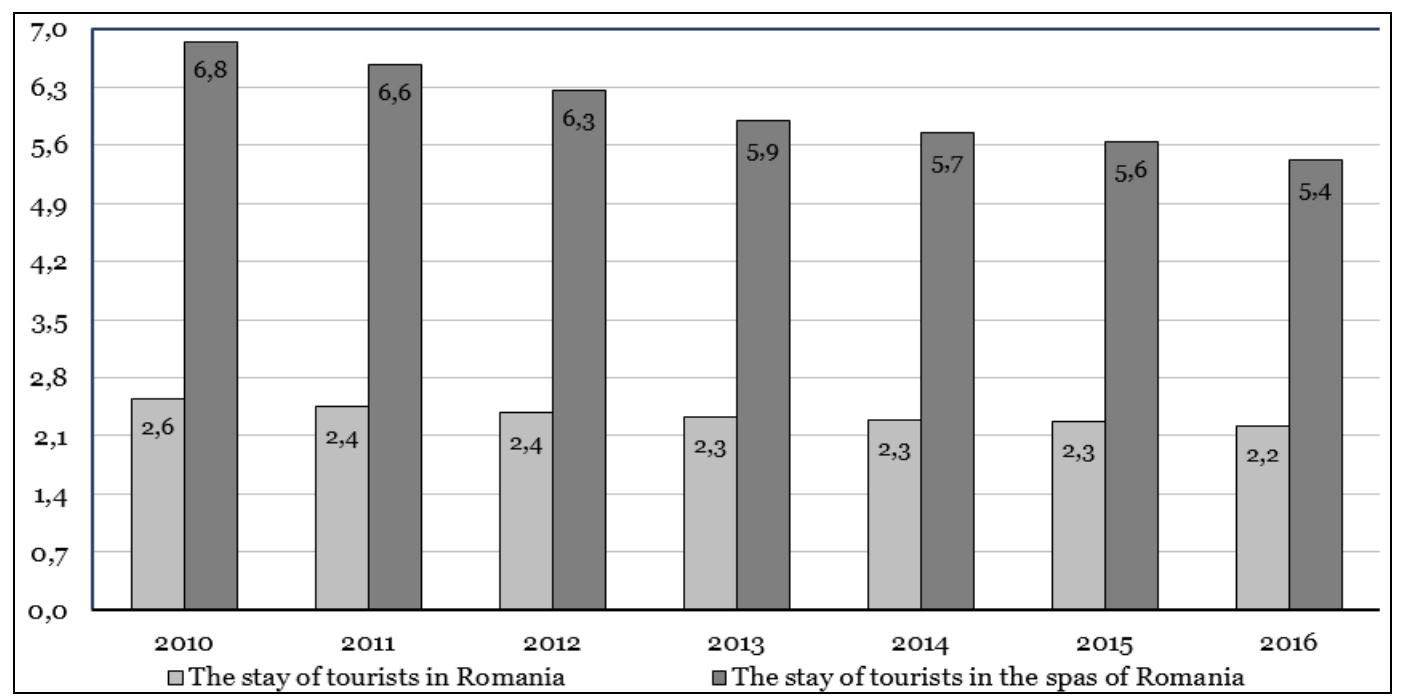

Figure 4. The average stay of the tourists in Romania and in the spas of Romania (Data source: own calculations from the data obtained from http://statistici.insse.ro/shop/)

\section{TOURISM CIRCULATION}

\section{The Tourist Arrivals}

According to the data obtained for this study from the Romanian National Institute of Statistics for the period 2010-2016, the highest share of tourist arrivals in Romania was registered in August, $14.3 \%$ of the total number of tourists arrivals of tourists in Romania, 
and the lowest share of tourist arrivals in Romania was registered in January, this month accounting for only $5.2 \%$ of the total arrivals of tourists in Romania. Considering a month of tourist season, that month's weight ratio is higher than the ratio between the maximum possible share $(100 \%)$ and the total number of months in a year (12), resulting in an average of 8.3(3)\%, we can say that in Romania, during 2010-2016, the tourist season in terms of arrivals of tourists was between May-September, when in $41.7 \%$ of the year there were $54.8 \%$ of the total of arrivals of tourists from Romania. At the same time, according to the same considerations, we can state that the tourist season in terms of arrivals of tourists was between October and April, when in $58.3 \%$ of the year there were $45.2 \%$ of the total arrivals of tourists in Romania (Figure 5, Table 1).

Within the spa resorts in Romania, the largest share of tourists 'arrivals was recorded also in August, this month accounting for $25.6 \%$ of the total arrivals of tourists in spa resorts in Romania, and the lowest share of tourists' arrivals in spa resorts in Romania was recorded in March, this month accounting for only 2.8\% of the total arrivals of tourists in spa resorts in Romania. The tourist season in the spa resorts in Romania, in terms of arrivals of tourists, ranges from June to September, when in the $33.3 \%$ of the year there were $66.2 \%$ of the total arrivals of the tourists in the spa resorts in Romania, and the tourist season, in terms of tourists' arrivals, ranged from October to May, when only $33.8 \%$ of the total arrivals of the tourists in the spa resorts in Romania accounted for $66.7 \%$ of the year (Figure 5, Table 1). Of the 20 spa resorts in Romania analyzed in this study, the majority had the maximum arrivals of tourists in August (with values between 13.7\% and 43.4\%).

Only three of them had the maximum arrivals of tourists in other months: in July Techirghiol (17.2\%) and Pucioasa (11.4\%) and Buziaș in September (10.9\%). At the opposite end, the fewer arrivals of tourists are more complex. In nine of the 20 resorts the minimum was recorded in January (with values between $0.1 \%$ and $4.5 \%$ ). In the other balneal stays, the minimum arrivals of tourists were registered in other months as follows: in November in Voineasa (2.8\%), in December in Geoagiu (4.1\%), in February in Slănic-Moldova (3.4\%), Sângeorz 0.4\%), Herculane (3.0\%) and Olănești (2.2\%), in March in Tuşnad (3.0\%), Sovata (5.5\%), Vatra Dornei (3.5\%), Govora (1.2\%) and CălimăneştiCăciulata 3.9\%) (Figure 5, Table 1). At the same time, depending on the number of tourists' arrivals in the spa resorts in Romania, 6 categories can be set according to the seasonality periods in the spa resorts in Romania (Figure 5, Table 1):

- 3 months (June-August): Mangalia-Olimp-Neptun;

- 4 months (June-September): Eforie Nord-Eforie Sud, Tușnad, Geoagiu and Sovata;

- 5 months (May-September): Herculane and Călimăneşti-Căciulata;

- 5 months (June to October): Moneasa and Techirghiol;

- 6 months (May-October): Slănic-Moldova, Felix-1 Mai, Sângeorz, Amara and Olănești;

- 7 months (May-November): Covasna, Pucioasa, Buziaş and Govora.

Among the 20 spa resorts analyzed are two cases where, because of their location in the mountainous areas, they have two tourist seasons, one in summer and one in winter. Thus, in Vatra Dornei the tourist seasons are in June-September and December-February, and in Voineasa the tourist seasons are in July-September and February (Figure 5, Table 1).

\section{The Tourist Overnight Stays}

Taking into account the same ratio, as in the tourists arrivals, between the maximum possible weight (100\%) and the total number of months in a year (12), it can be stated that, from the point of view of tourists' overnight stays in Romania, the tourism season was between June and September, when in the $33.3 \%$ of the year there were $52.3 \%$ of the total number of overnight stays of tourists in Romania, while the tourist season in terms of overnight stays was between October and May, when 66.7\% of the year recorded $47.7 \%$ of the total number of overnight stays in Romania (Figure 5, Table 2). 

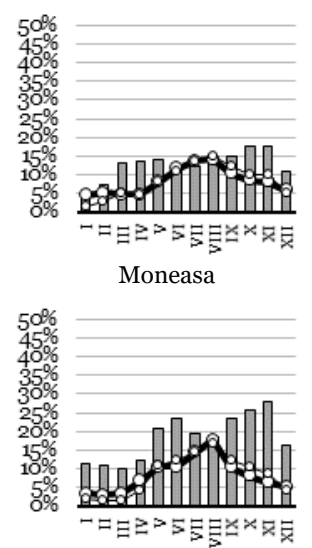

Herculane

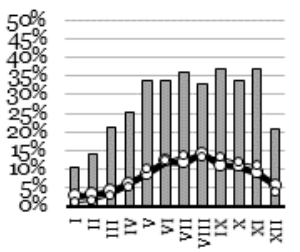

Covasna

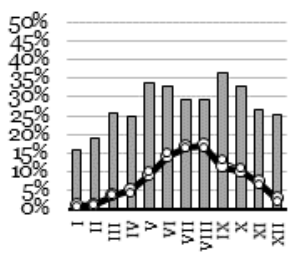

Amara

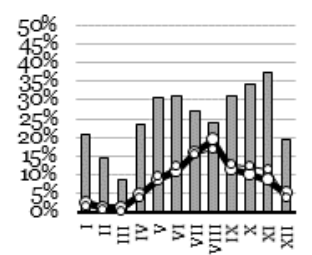

Govora
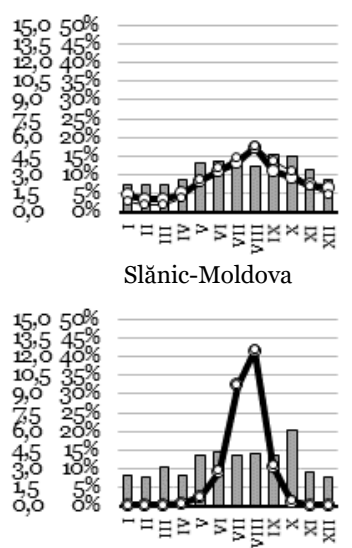

Eforie Nord-Eforie Sud

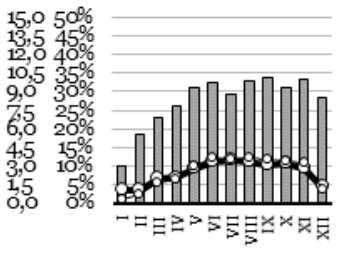

Pucioasa
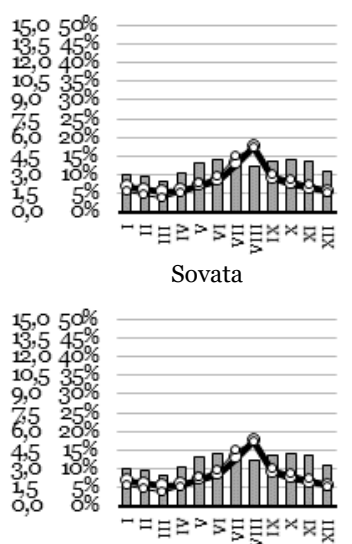

Olãneşti

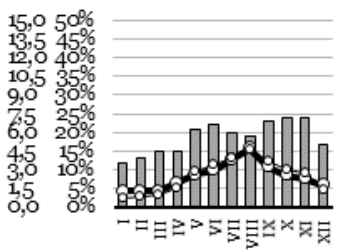

Felix-1 Mai
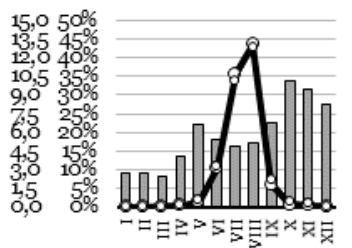

Mangalia-Olimp-Neptun

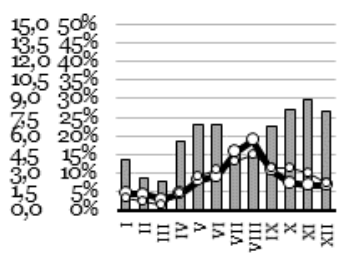

Tuşnad

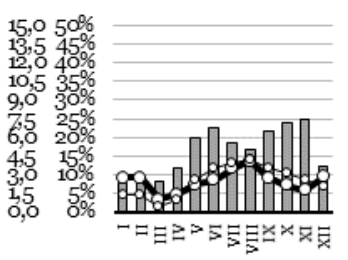

Vatra Dornei

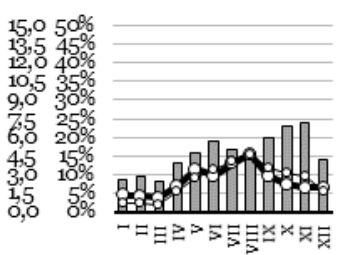

Călimăneşti-Căciulata
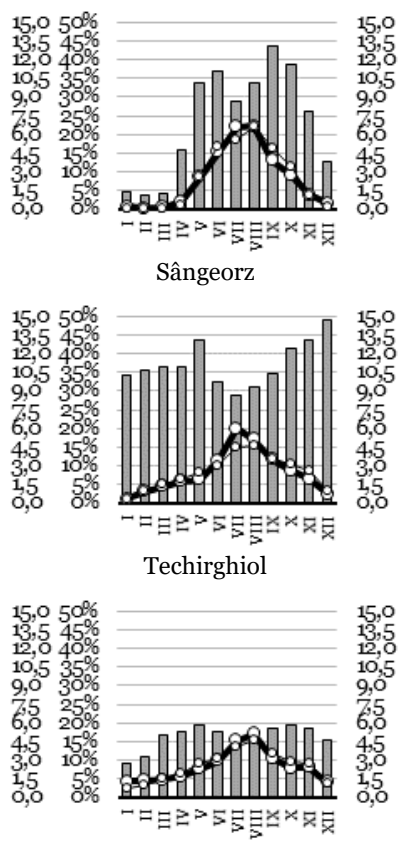

Geoagiu
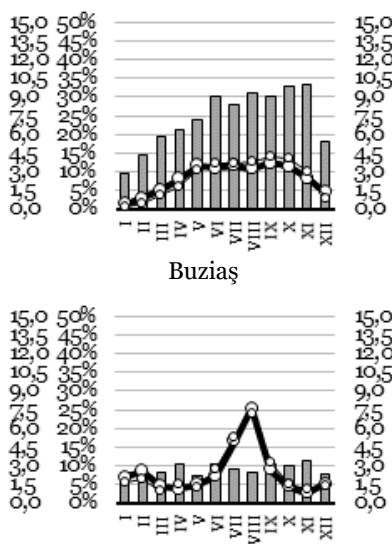

Voineasa

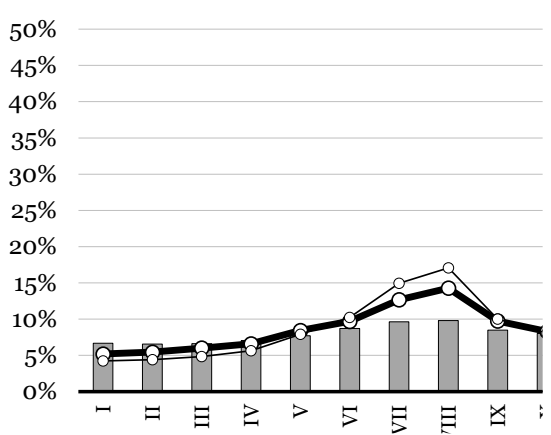

Figure 5. The average tourist stay, arrivals and staying overnight of touristsin spas of Romania and Romania (Data source: own calculations from the data obtained from http://statistici.insse.ro/shop/) 
Tourism Seasonality in the Spas of Romania

Table 1. Tourists in accommodation facilities

(Data source: own calculations from the data obtained from http://statistici.insse.ro/shop/)

\begin{tabular}{|c|c|c|c|c|c|c|c|c|c|c|c|c|}
\hline Spa & Jan & Feb & Mar & Apr & May & Jun & Jul & Aug & Sep & Oct & Nov & Dec \\
\hline Moneasa & $4.5 \%$ & $5.2 \%$ & $4.7 \%$ & $4.8 \%$ & $8.1 \%$ & $11.6 \%$ & $13.8 \%$ & $14.3 \%$ & $10.4 \%$ & $8.5 \%$ & $8.1 \%$ & $5.9 \%$ \\
\hline Slănic-Moldova & $4.5 \%$ & $3.4 \%$ & $3.4 \%$ & $5.0 \%$ & $8.4 \%$ & $11.0 \%$ & $13.2 \%$ & $17.2 \%$ & $11.0 \%$ & $9.2 \%$ & $7.3 \%$ & $6.5 \%$ \\
\hline Băile Felix-1 Mai & $4.3 \%$ & $4.3 \%$ & $4.4 \%$ & $6.6 \%$ & $8.8 \%$ & $9.9 \%$ & $\mathbf{1 2 . 8 \%}$ & $15.9 \%$ & $10.9 \%$ & $8.6 \%$ & $7.7 \%$ & $5.8 \%$ \\
\hline Sângeorz-Băi & $0.8 \%$ & $0.4 \%$ & $0.6 \%$ & $2.1 \%$ & $8.7 \%$ & $15 \cdot 3 \%$ & $21.9 \%$ & $\mathbf{2 2 . 1 \%}$ & $13.1 \%$ & $9.3 \%$ & $3.9 \%$ & $1.8 \%$ \\
\hline Băile Herculane & $3.4 \%$ & $3.0 \%$ & $3.5 \%$ & $6.7 \%$ & $10.5 \%$ & $10.7 \%$ & $14.4 \%$ & $17.7 \%$ & $10.4 \%$ & $8.2 \%$ & $6.3 \%$ & $5.2 \%$ \\
\hline Eforie Nord-Eforie Sud & $0.2 \%$ & $0.3 \%$ & $0.3 \%$ & $0.8 \%$ & $2.6 \%$ & $9.2 \%$ & $32.4 \%$ & $41.4 \%$ & $10.7 \%$ & $1.1 \%$ & $0.4 \%$ & $0.4 \%$ \\
\hline Mangalia-Olimp-Neptun & $0.1 \%$ & $0.2 \%$ & $0.2 \%$ & $0.5 \%$ & $1.5 \%$ & $10.6 \%$ & $35 \cdot 7 \%$ & $43.4 \%$ & $6.2 \%$ & $0.8 \%$ & $0.6 \%$ & $0.2 \%$ \\
\hline Techirghiol & $1.3 \%$ & $3.2 \%$ & $4.7 \%$ & $5.9 \%$ & $6.4 \%$ & $11.6 \%$ & $\mathbf{2 0 . 0 \%}$ & $17.2 \%$ & $11.7 \%$ & $8.9 \%$ & $6.7 \%$ & $2.5 \%$ \\
\hline Covasna & $2.7 \%$ & $3.3 \%$ & $4.1 \%$ & $6.2 \%$ & $8.9 \%$ & $12.2 \%$ & $11.7 \%$ & $14 \cdot 3 \%$ & $11.1 \%$ & $10.8 \%$ & $9.1 \%$ & $5.7 \%$ \\
\hline Pucioasa & $3.6 \%$ & $3.7 \%$ & $6.7 \%$ & $7.1 \%$ & $9.5 \%$ & $11.3 \%$ & $11.6 \%$ & $11.4 \%$ & $10.4 \%$ & $10.8 \%$ & $9.5 \%$ & $4.5 \%$ \\
\hline Băile Tuşnad & $4.6 \%$ & $4.3 \%$ & $3.0 \%$ & $4.7 \%$ & $8.1 \%$ & $9.2 \%$ & $15.7 \%$ & $18.8 \%$ & $10.7 \%$ & $7.6 \%$ & $6.8 \%$ & $6.7 \%$ \\
\hline Geoagiu-Băi & $4.3 \%$ & $4.6 \%$ & $4.8 \%$ & $5 \cdot 7 \%$ & $7.7 \%$ & $9.9 \%$ & $15.2 \%$ & $17.0 \%$ & $10.5 \%$ & $8.0 \%$ & $8.0 \%$ & $4.1 \%$ \\
\hline Amara & $0.9 \%$ & $1.3 \%$ & $3.7 \%$ & $5.2 \%$ & $9.3 \%$ & $14.3 \%$ & $16.7 \%$ & $17.0 \%$ & $11.4 \%$ & $10.1 \%$ & $7.3 \%$ & $2.7 \%$ \\
\hline Sovata & $6.9 \%$ & $6.1 \%$ & $5.5 \%$ & $6.0 \%$ & $7.3 \%$ & $8.6 \%$ & $13.0 \%$ & $17.5 \%$ & $9.2 \%$ & $7.7 \%$ & $6.6 \%$ & $5.7 \%$ \\
\hline Vatra Dornei & $9.2 \%$ & $9.2 \%$ & $3.5 \%$ & $4.8 \%$ & $7.4 \%$ & $8.6 \%$ & $11.7 \%$ & $13.7 \%$ & $9.2 \%$ & $7 \cdot 3 \%$ & $5.8 \%$ & $9.5 \%$ \\
\hline Buziaş & $1.4 \%$ & $3.0 \%$ & $5 \cdot 3 \%$ & $8.0 \%$ & $11.6 \%$ & $11.2 \%$ & $11.7 \%$ & $10.9 \%$ & $12.5 \%$ & $11.5 \%$ & $8.4 \%$ & $4.6 \%$ \\
\hline Băile Govora & $2.6 \%$ & $1.2 \%$ & $1.2 \%$ & $4.7 \%$ & $8.7 \%$ & $10.9 \%$ & $15.9 \%$ & $19.3 \%$ & $11.6 \%$ & $10.1 \%$ & $8.7 \%$ & $5.1 \%$ \\
\hline Băile Olãnești & $3.2 \%$ & $2.2 \%$ & $3.0 \%$ & $4.9 \%$ & 9.1\% & $11.7 \%$ & $15.0 \%$ & $17.2 \%$ & $11.7 \%$ & $10.1 \%$ & $6.4 \%$ & $5 \cdot 3 \%$ \\
\hline Călimăneşti-Căciulata & $4.6 \%$ & $4.2 \%$ & $3.9 \%$ & $7.0 \%$ & $11.5 \%$ & $9.8 \%$ & $12.9 \%$ & $15.6 \%$ & $9.7 \%$ & $7 \cdot 5 \%$ & $6.6 \%$ & $6.7 \%$ \\
\hline Voineasa & $7.1 \%$ & $8.7 \%$ & $4.5 \%$ & $3.8 \%$ & $5.1 \%$ & $7.4 \%$ & $16.7 \%$ & $25.3 \%$ & $9.1 \%$ & $4.5 \%$ & $2.8 \%$ & $5.1 \%$ \\
\hline Total Spa & $3.0 \%$ & $2.9 \%$ & $2.8 \%$ & $4.2 \%$ & $6.5 \%$ & $10.2 \%$ & $20.9 \%$ & $25.6 \%$ & $9.5 \%$ & $5.8 \%$ & $4.8 \%$ & $3.9 \%$ \\
\hline Romania & $5.2 \%$ & $5.4 \%$ & $6.0 \%$ & $6.6 \%$ & $8.4 \%$ & $9.7 \%$ & $12.7 \%$ & $14.3 \%$ & $9.7 \%$ & $8.3 \%$ & $7.2 \%$ & $6.4 \%$ \\
\hline
\end{tabular}

The largest share of tourists 'overnight stays in spa resorts in Romania was recorded, as in the case of tourists' arrivals in spa resorts in Romania also in August, when $24.0 \%$ of the total number of overnight stays in the spa resorts in Romania were registered, and the lowest share of tourists' nights in spa resorts in Romania was in January, when only $1.6 \%$ of the total number of overnight stays of tourists in spa resorts in Romania was recorded. From the data analysis, it can be said that in terms of tourist overnights in the spa resorts in Romania, the tourist season is between June and September, when in $33.3 \%$ of the year there were $66.5 \%$ of the total overnight stays of tourists in spa resorts in Romania, while the tourist season is between June and September, when $66.5 \%$ of the year recorded $33.5 \%$ of the total number of overnight stays in the spa resorts in Romania (Figure 5, Table 2).

Most of the 20 spa resorts in Romania, analyzed in this study had the maximum tourist overnight stays in 2010-2016 (with values between $12.4 \%$ and 42.6\%). However, in three of the spa resorts in Romania, the maximum overnight stays of tourists were recorded in other months: in July in Covasna (13.8\%) and Amara (16.2\%), and Buziaş in September (13.9\%). As for the fewest overnight stays of tourists, the situation is more complex. Thus, in 11 of the 20 spa resorts, the minimum tourist overnight was registered in January (with values ranging from $0.1 \%$ to $2.7 \%$ ), in 6 out of the 20 spa resorts the minimum tourist overnight was registered in January (with values ranging from $0.4 \%$ to $3.8 \%$ ), and in 6 of the 20 spa resorts, the minimum tourist overnight stays was also registered in January (with values between $0.04 \%$ and $2.1 \%$ ).

Depending on the percentage of tourists' nights spent in spa resorts in Romania, a total of 6 categories can be set according to the tourist seasonality periods in the spa resorts in Romania (Figure 5, Table 2):

- 3 months (June-August): Mangalia-Olimp-Neptun;

- 4 months (June-September): Eforie Nord-Eforie Sud and Voineasa;

- 5 months (June to October): Sovata;

- 6 months (May-October): Slănic-Moldova, Sângeorz and Amara; 
- 6 months (June to November): Techirghiol;

- 7 months (May-November): Moneasa, Felix-1 Mai, Herculane, Covasna, Pucioasa, Tușnad, Geoagiu-Băi, Vatra Dornei, Buziaş, Govora, Olănești and Călimăneşti-Căciulata.

Table 2. Overnight stays of the tourists in the structure of tourists accomodation (Data source: own calculations from the data obtained from http://statistici.insse.ro/shop/)

\begin{tabular}{|c|c|c|c|c|c|c|c|c|c|c|c|c|}
\hline Spa & Jan & Feb & Mar & Apr & May & Jun & Jul & Aug & Sep & Oct & Nov & Dec \\
\hline Moneasa & $1.6 \%$ & $2.9 \%$ & $5.0 \%$ & $4.7 \%$ & $8.4 \%$ & $11.1 \%$ & $13.7 \%$ & $15.2 \%$ & $12.3 \%$ & $10.2 \%$ & $9.9 \%$ & $5.1 \%$ \\
\hline Slănic-Moldova & $2.9 \%$ & $2.1 \%$ & $2.2 \%$ & $3.8 \%$ & $8.8 \%$ & $12.0 \%$ & $14 \cdot 3 \%$ & $17.9 \%$ & $13.8 \%$ & $10.9 \%$ & $6.8 \%$ & $4.7 \%$ \\
\hline Băile Felix-1 Mai & $2.7 \%$ & $2.9 \%$ & $3.4 \%$ & $5.1 \%$ & $9.4 \%$ & $11.2 \%$ & $13 \cdot 3 \%$ & $15.5 \%$ & $12.5 \%$ & $10.2 \%$ & $9.1 \%$ & $4.8 \%$ \\
\hline Sângeorz-Băi & $0.1 \%$ & $0.0 \%$ & $0.1 \%$ & $1.1 \%$ & $8.9 \%$ & $16.6 \%$ & $18.7 \%$ & $21.9 \%$ & $16.5 \%$ & $11.3 \%$ & $3.9 \%$ & $0.9 \%$ \\
\hline Băile Herculane & $1.9 \%$ & $1.6 \%$ & $1.7 \%$ & $4.1 \%$ & $11.1 \%$ & $12.3 \%$ & $14.4 \%$ & $16.8 \%$ & $12.5 \%$ & $10.6 \%$ & $8.7 \%$ & $4.2 \%$ \\
\hline Eforie Nord-Eforie Sud & $0.1 \%$ & $0.2 \%$ & $0.2 \%$ & $0.5 \%$ & $2.4 \%$ & $9.5 \%$ & $32.5 \%$ & $41.9 \%$ & $10.8 \%$ & $1.5 \%$ & $0.2 \%$ & $0.2 \%$ \\
\hline Mangalia-Olimp-Neptun & $0.1 \%$ & $0.1 \%$ & $0.1 \%$ & $0.4 \%$ & $2.0 \%$ & $11.0 \%$ & $33 \cdot 5 \%$ & $42.6 \%$ & $7.4 \%$ & $1.4 \%$ & $1.0 \%$ & $0.3 \%$ \\
\hline Techirghiol & $1.3 \%$ & $3.5 \%$ & $5.0 \%$ & $6.3 \%$ & $8.3 \%$ & $10.3 \%$ & $15.1 \%$ & $15.6 \%$ & $11.7 \%$ & $10.7 \%$ & $8.8 \%$ & $3.5 \%$ \\
\hline Covasna & $0.9 \%$ & $1.5 \%$ & $2.9 \%$ & $5.2 \%$ & $9.9 \%$ & $12.4 \%$ & $13.8 \%$ & $13 \cdot 3 \%$ & $13 \cdot 3 \%$ & $11.9 \%$ & $10.9 \%$ & $3.9 \%$ \\
\hline Pucioasa & $1.2 \%$ & $2.6 \%$ & $5.6 \%$ & $6.4 \%$ & $10.0 \%$ & $12.2 \%$ & $11.6 \%$ & $12.4 \%$ & $11.8 \%$ & $11.5 \%$ & $10.8 \%$ & $4.0 \%$ \\
\hline Băile Tuşnad & $3.2 \%$ & $2.6 \%$ & $1.3 \%$ & $4.6 \%$ & $\mathbf{9 . 1} \%$ & $11.0 \%$ & $13.1 \%$ & $14.9 \%$ & $11.3 \%$ & $11.3 \%$ & $10.1 \%$ & $7.5 \%$ \\
\hline Geoagiu-Băi & $2.7 \%$ & $3.3 \%$ & $5.2 \%$ & $6.5 \%$ & $9.1 \%$ & $10.3 \%$ & $13.5 \%$ & $15.2 \%$ & $11.9 \%$ & $9.8 \%$ & $9.0 \%$ & $3.6 \%$ \\
\hline Amara & $0.7 \%$ & $1.3 \%$ & $3.6 \%$ & $4.2 \%$ & $10.2 \%$ & $15.0 \%$ & $16.2 \%$ & $16.1 \%$ & $13 \cdot 3 \%$ & $10.9 \%$ & $6.5 \%$ & $1.9 \%$ \\
\hline Sovata & $5.7 \%$ & $4.7 \%$ & $3.8 \%$ & $5.0 \%$ & $7.8 \%$ & $9.7 \%$ & $15.1 \%$ & $17.1 \%$ & $10.2 \%$ & $8.5 \%$ & $7.3 \%$ & $5.0 \%$ \\
\hline Vatra Dornei & $4.5 \%$ & $4.6 \%$ & $1.8 \%$ & $3.5 \%$ & $8.9 \%$ & $11.7 \%$ & $13.2 \%$ & $13.9 \%$ & $11.9 \%$ & $10.6 \%$ & $8.5 \%$ & $7.0 \%$ \\
\hline Buziaş & $0.5 \%$ & $1.7 \%$ & $4.0 \%$ & $6.2 \%$ & $10.5 \%$ & $12.2 \%$ & $12.2 \%$ & $12.6 \%$ & $13.9 \%$ & $13.4 \%$ & $10.1 \%$ & $2.9 \%$ \\
\hline Băile Govora & $1.4 \%$ & $0.5 \%$ & $0.4 \%$ & $3.7 \%$ & $9.7 \%$ & $12.3 \%$ & $15.5 \%$ & $16.6 \%$ & $12.5 \%$ & $12.4 \%$ & $11.3 \%$ & $3.6 \%$ \\
\hline Băile Olãneşti & $1.0 \%$ & $1.5 \%$ & $3.1 \%$ & $4.7 \%$ & $10.1 \%$ & $12.6 \%$ & $14.2 \%$ & $15.7 \%$ & $12.8 \%$ & $11.8 \%$ & $9.1 \%$ & $3.4 \%$ \\
\hline Călimăneşti-Căciulata & $2.3 \%$ & $2.3 \%$ & $2.0 \%$ & $5 \cdot 7 \%$ & $9.2 \%$ & $11.6 \%$ & $13.8 \%$ & $15.4 \%$ & $11.9 \%$ & $10.7 \%$ & $9.7 \%$ & $5.4 \%$ \\
\hline Voineasa & $5.7 \%$ & $6.4 \%$ & $3.5 \%$ & $5.3 \%$ & $4.3 \%$ & $9.1 \%$ & $17.6 \%$ & $\mathbf{2 3 . 8 \%}$ & $10.9 \%$ & $5.1 \%$ & $3.6 \%$ & $4.9 \%$ \\
\hline Total Spa & $1.6 \%$ & $1.7 \%$ & $2.1 \%$ & $3.5 \%$ & $7.2 \%$ & $11.4 \%$ & $20.0 \%$ & $24.0 \%$ & $11.1 \%$ & $7.8 \%$ & $6.4 \%$ & $3.2 \%$ \\
\hline Romania & $4.2 \%$ & $4.4 \%$ & $4.8 \%$ & $5.6 \%$ & $7.9 \%$ & $10.2 \%$ & $14.9 \%$ & $\mathbf{1 7 . 1 \%}$ & $10.0 \%$ & $8.1 \%$ & $7.0 \%$ & $5.6 \%$ \\
\hline
\end{tabular}

\section{The Average Tourist Stays}

The tourist season periods according to the average monthly stay were calculated according to the annual average of the stay. Thus, the months in which the average monthly staying was higher than the average annual stay, were considered as months belonging to the tourism season. It is worth noting that these periods were determined by the annual average stay obtained in turn from the ratio between the annual number of overnight stays of tourists and the annual number of tourists' arrivals.

Depending on the quality of services offered by spa resorts (Stupariu \& Josan, 2014), as well as the types of procedures and treatments and the therapeutic recommendations respectively, the average stay has different values from one spa resort, to another spa resort. It should also be noted that medical tourism is mostly practiced in spa resorts, which is another reason for the differences in the average stay. Thus, average annual tours with great value are recorded in spa resorts: Techirghiol (11.2 days/stay), Olănești (8.4 days/stay), Covasna (8.4 days/stay), Amara (8.3 days) and Pucioasa day / night). At the opposite end, smaller annual average tourist stays are recorded in the spa resorts: Voineasa (2.7 days/stay), Slănic-Moldova (3.3 days/stay), Eforie Nord-Eforie Sud (3.5 days/stay) and Moneasa (3.8 days/stay) (Figure 5, Table 3).

For most spa resorts, the tourist season, from the point of view of the average stay, is between May and November (situation found in 9 of the 20 cases).

A distinct element in the average stay is the existence of lower average values than the previous and the following months in the maximum period of arrivals of tourists and maximum of tourists' overnight stays. This situation is found in 17 out of 20 spa resorts (Figure 4, Table 3). In some of these 17 spa resorts, the size of the average stay decreases 
Tourism Seasonality in the Spas of Romania

so much that one can speak of an extra off-season for the average stay. Such situations are found in 7 of the 17 spa resorts. In Voineasa resort the average annual stay is exceeded in three cases: in April, June-July and September-November (Figure 5, Table 3).

Table 3. The average stay of the tourists in the structure of tourists accomodation (Data source: own calculations from the data obtained from http://statistici.insse.ro/shop/)

\begin{tabular}{|c|c|c|c|c|c|c|c|c|c|c|c|c|c|}
\hline Spa & Jan & Feb & Mar & Apr & May & Jun & Jul & Aug & Sep & Oct & Nov & Dec & Avr \\
\hline Moneasa & 1.4 & 2.2 & $3 \cdot 9$ & 4.0 & 4.2 & 3.7 & 3.7 & 4.0 & $4 \cdot 5$ & $5 \cdot 3$ & $5 \cdot 3$ & $3 \cdot 3$ & 3.8 \\
\hline Slănic-Moldova & 2.2 & 2.3 & 2.2 & 2.7 & 4.0 & 4.1 & 3.9 & $3 \cdot 7$ & 4.6 & $4 \cdot 5$ & $3 \cdot 4$ & 2.7 & $3 \cdot 3$ \\
\hline Băile Felix-1 Mai & 3.6 & 3.9 & 4.5 & 4.6 & 6.3 & 6.7 & 6.0 & $5 \cdot 7$ & 6.9 & 7.1 & 7.2 & 5.0 & 5.6 \\
\hline Sângeorz-Băi & 1.3 & 1.1 & 1.3 & 4.8 & 10.2 & 11.1 & 8.6 & 10.1 & 13.0 & 11.7 & 7.9 & 3.9 & 7.1 \\
\hline Băile Herculane & 3.4 & $3 \cdot 3$ & 3.0 & 3.7 & 6.2 & 7.0 & 5.8 & 5.5 & 7.1 & $7 \cdot 7$ & $\mathbf{8 . 3}$ & 4.9 & $5 \cdot 5$ \\
\hline Eforie Nord-Eforie Sud & 2.5 & 2.3 & 3.1 & 2.5 & 4.0 & $4 \cdot 3$ & 4.2 & 4.2 & 4.1 & 6.1 & 2.7 & 2.3 & 3.5 \\
\hline Mangalia-Olimp-Neptun & 2.7 & 2.7 & 2.5 & 4.1 & 6.7 & $5 \cdot 5$ & 4.9 & 5.1 & 6.8 & 10.1 & 9.4 & 8.3 & $5 \cdot 7$ \\
\hline Techirghiol & 10.3 & 10.6 & 10.9 & 10.9 & 13.1 & 9.8 & 8.6 & 9.3 & 10.4 & 12.4 & 13.1 & $14 \cdot 7$ & 11.2 \\
\hline Covasna & 3.1 & 4.2 & 6.4 & 7.5 & 10.1 & 10.1 & 10.8 & 9.9 & 11.1 & 10.1 & 11.0 & 6.3 & 8.4 \\
\hline Pucioasa & 3.0 & 5.6 & 6.9 & 7.9 & 9.3 & 9.7 & 8.8 & 9.8 & 10.2 & 9.3 & 10.0 & 8.5 & 8.3 \\
\hline Băile Tuşnad & 4.0 & 2.6 & 2.4 & 5.6 & 6.9 & 7.0 & 5.2 & 4.7 & 6.8 & 8.2 & 8.9 & 7.9 & 5.8 \\
\hline Geoagiu-Băi & 2.8 & $3 \cdot 3$ & 5.0 & $5 \cdot 3$ & 5.8 & 5.2 & 4.4 & 4.5 & $5 \cdot 5$ & 5.9 & $5 \cdot 5$ & 4.6 & 4.8 \\
\hline Amara & 4.8 & $5 \cdot 7$ & 7.7 & 7.4 & 10.2 & 9.8 & 8.8 & 8.8 & 11.0 & 9.9 & 8.0 & 7.6 & 8.3 \\
\hline Sovata & 3.1 & 2.8 & 2.5 & 3.2 & 3.9 & 4.3 & 4.4 & 3.6 & 4.1 & 4.2 & 4.1 & $3 \cdot 3$ & 3.6 \\
\hline Vatra Dornei & 2.4 & 2.5 & 2.5 & 3.6 & 5.9 & 6.8 & 5.6 & 5.1 & 6.4 & 7.2 & $7 \cdot 4$ & 3.6 & 4.9 \\
\hline Buziaş & 2.9 & 4.3 & 5.8 & 6.3 & 7.2 & 9.1 & 8.3 & 9.3 & 9.0 & 9.8 & 9.9 & $5 \cdot 4$ & $7 \cdot 3$ \\
\hline Băile Govora & 6.3 & 4.4 & 2.7 & 7.0 & 9.1 & 9.3 & 8.1 & 7.1 & 9.3 & 10.3 & 11.1 & 5.8 & $7 \cdot 5$ \\
\hline Băile Olãneşti & 3.1 & 6.4 & 9.0 & 8.5 & 9.7 & 9.4 & 8.3 & 8.0 & 9.7 & 10.2 & 12.5 & 5.8 & 8.4 \\
\hline Călimăneşti-Căciulata & 2.7 & 2.8 & 2.5 & 4.0 & $4 \cdot 7$ & $5 \cdot 7$ & 5.0 & 4.7 & 5.9 & 6.9 & 7.2 & 4.2 & 4.7 \\
\hline Voineasa & 2.2 & 2.3 & 2.4 & 3.1 & 2.2 & 3.1 & 2.7 & 2.4 & 3.2 & 3.0 & 3.4 & 2.4 & 2.7 \\
\hline Total Spa & 3.3 & 3.8 & 4.3 & $5 \cdot 3$ & 7.0 & 7.1 & 6.3 & 6.3 & 7.5 & 8.0 & 7.8 & 5.5 & 6.0 \\
\hline Romania & 2.0 & 2.0 & 2.0 & 2.1 & 2.3 & 2.6 & 2.9 & 2.9 & 2.5 & 2.4 & 2.4 & 2.1 & 2.6 \\
\hline
\end{tabular}

\section{CONCLUSIONS}

From the point of view of tourist arrivals and overnight stays in Romanian spa resorts, the tourist season ranges from June to September, and from the point of view of overall overnight stays, the tourist season is between May and November. It is worth noting that these tourist season periods are medium and they are overlapping over favorable periods in many ways (climate, economic, social etc). Following a separate analysis of the individual resorts it can be stated that the seasonality in the spa resorts in Romania has distinct characteristics determined by the particular situations encountered in each of the 20 resorts or groups of resorts considered in this study.

Among its many advantages, seasonality allows the tour operators to formulate objective decisions based on a logical, verifiable and operational methodology, creating a background of market trends in most of the time and in most markets, and providing historically valid inputs to support other analytical methods and timing indicators. The essence of seasonality is found in its long history and statistical testable methodologies.

Seasonal character and its economic, social and environmental impacts are a major issue for the tourism industry.

\section{REFERENCES}

Ahas, R., Aasa, A., Mark, U., Pae, T., \& Kull, A. (2007). Seasonal tourism spaces in Estonia: Case study with mobile positioning data. Tourism Management, Vol. 28, Issue 3, pp. 898-910.

Baum, T. (1999). Seasonality in tourism: understanding the challenges. Tourism Economics, 1999, 5 (1), pp. 5-8;

Bârsan, Mihaela, \& Șușu, Ș. (2013). Analiza economico-financiară în comerț și turism [Economic and financial analysis in trade and tourism], Editura Didactică și Pedagogică, București. 
Bell, W.R., Holan, S.H., \& McElroy, T.S. (2012). Economic Time Series: Modeling and Seasonality. Editura CRC Press, Boca Raton.

Biljana, Petrevska. (2013). Empirical Analysis of Seasonality Patterns in Tourism. Journal of Process Management - New Technologies, International Vol. 1, No.2, 2013.

Borges, Lima, Cilénia. (2013). The Role of Cultural Tourism in Seasonality Reduction: The Case of Cape Verde. Project submitted as partial requirement for the conferral of Master of Science in Business Administration, ISCTE Business Scholl, Lisbon University Institute, https://repositorio.iscteiul.pt/bitstream/10071/8014/1/final_MScBA_thesis_Cil\%C3\%A9niaBorges.pdf.

Butler, R. (1998). Seasonality in tourism: Issues and implications. The Tourist Review, Vol. 53 Issue: 3, pp. 18-24;

Commons J., \& Page, S. (2001). Managing Seasonality in Peripheral Tourism Regions: The Case of Northland. New Zealand, în Baum, T., Lundtrop, S:, (editori), Seasonality in Tourism, Editura Pergamon, Amsterdam, pp. 153-172.

Connell Joanne, Page J.S., \& Meyer, D. (2015). Visitor attractions and events: Responding to seasonality. Tourism Management, Elsevier, No. 46, pp. 283-298.

Deery Margaret, Kenneth, L.J., \& Mair, Judith. (2009). Dealing With Change: The Impacts of Seasonality on Tourism Operators. In: CAUTHE 2009: See Change Tourism and Hospitality in a Dynamic World, Carlsen J., Hughes M., Holmes Kirsten, Roy J., eds., Curtin University of Technology, Fremantle, Western Australia, pp. 707-735.

Ilieş Camelia Dorina, Ilieş A., Herman V.G., Baias Ş., \& Morar C. (2011). Geotourist Map of the Băile Felix Băile 1 Mai - Betfia Area (Bihor County, Romania). GeoJournal of Tourism and Geosites, Year IV, 2011/2, Volume 8, pp. 219-226.

Jang, S. (2004). Mitigating tourism seasonality: A Quantitative Approach. Annals of Tourism Research, Vol. 31, Issue 4, pp. 819-836.

Karadzhov, V. (2014). Spa and wellness tourism in tackling with seasonality of tourism services in SouthWestern Bulgaria. paper for the Conference: International Tourist Forum SPA and Wine, Sandanski, Bulgaria, Corfu, Greece, Vol. 1 https://www.researchgate.net/publication/304014935_Spa_and_ wellness_tourism_in_tackling_with_seasonality_of_tourism_services_in_South-Western_Bulgaria.

Koca, E., \& Altinay, G. (2007). An analysis of seasonality in monthly per person tourist spending in Turkish inbound tourism from a market segmentation perspective. Tourism Management, Vol. 28, pp 227-237.

Maghsoodi Tilaki J.M., Hedayati-Marzbali M., Abdullah A., \& Mohsenzadeh M. (2017). Towards Tourism Development: Bridging the Gap Between Tourists' Expectations and Satisfaction. GeoJournal of Tourism and Geosites, Year X, 2017 / 1, Volume 19, pp. 104-114.

Manning R.E., \& Powers L. (1984). Peak and Off Peak Use: Redistributing the Outdoor Recreation/Tourism Load. Journal of Travel Research, 23 (2), pp. 25-31.

Marcu F. (2000). Marele dicționar de neologisme [The Great Dictionary of Neologisms], Editura Saeculum, București.

Morse S.C., \& Smith M. Eva. (2015). Employment Impacts of Off-Peak Seasonal Tourism Development, Business and Economics Journal 6:150.

Rizal P., \& Asokan R. (2014). Seasonality of Tourism: A Major Constraint for the Growth of Tourism in the Regional Economy of Sikkim State, India, International Journal of Current Research, Vol. 6, Issue, o6, pp. 7211-7218.

Stupariu, I.M., \& Josan Ioana. (2014). The Quality of Hotel Services. Case study: The County Seat Municipalities of the North-West Development Region. GeoJournal of Tourism and Geosites, Year VII, no. 2, vol. 14, November 2014, pp. 207-214.

Zaman G., \& Geamănu Marinela. (2006). Eficiența economică [Economic efficiency]. Editura Fundației România de mâine, București.

*** (2008). Hotărâre nr. 852 din 13 august 2008 pentru aprobarea normelor si criteriilor de atestare a staţiunilor turistice [Decision no. 852 of August 13, 2008 for the approval of the norms and criteria for attestation of tourist resorts], Emitent: Guvernul României, publicată în: Monitorul Oficial nr. 613 din 20 august 2008, data intrării in vigoare: 20 August 2008.

*** (2009). Dicționarul explicativ al limbii române [The Explanatory Dictionary of the Romanian language], ediția a II-a revăzută și adăugită, (DEX), Academia Română, Institutul de Lingvistică "Iorgu Iordan Alexandru Rosetti”, Editura Univers Enciclopedic, București.

http://www.insse.ro.

http://statistici.insse.ro/shop.

Submitted:

26.03.2018
Revised:

10.09.2018
Accepted and published online 12.09.2018 